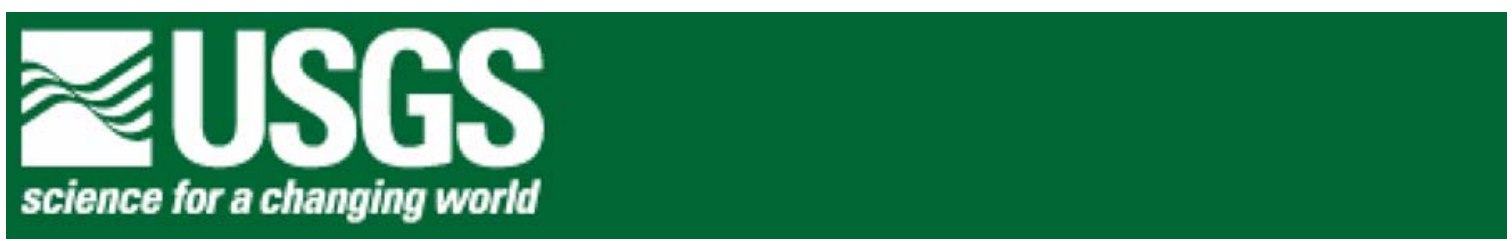

\title{
Gravity Data from Newark Valley, White Pine County, Nevada
}

By Edward A. Mankinen and Edwin H. McKee

\section{U.S. Geological Survey}

Open File Report 2007-1306

2007

U.S. Department of the Interior

U.S. Geological Survey 


\section{U.S. Department of the Interior DIRK KEMPTHORNE, Secretary}

\section{U.S. Geological Survey \\ Mark D. Myers, Director}

U.S. Geological Survey, Reston, Virginia 2007

For product and ordering information:

World Wide Web: http://www.usgs.gov/pubprod

Telephone: 1-888-ASK-USGS

For more information on the USGS - the Federal source for science about the Earth, its natural and living resources, natural hazards, and the environment:

World Wide Web: http://www.usgs.gov

Telephone: 1-888-ASK-USGS

Suggested citation:

Mankinen, Edward A., and McKee, Edwin H., 2007, Gravity data from Newark Valley, White Pine County, Nevada: U.S. Geological Survey Open File Report 2007-1306

[http://pubs.usgs.gov/of/2007/1306].

Any use of trade, product, or firm names is for descriptive purposes only and does not imply endorsement by the U.S. Government.

Although this report is in the public domain, permission must be secured from the individual copyright owners to reproduce any copyrighted material contained within this report. 


\section{Contents}

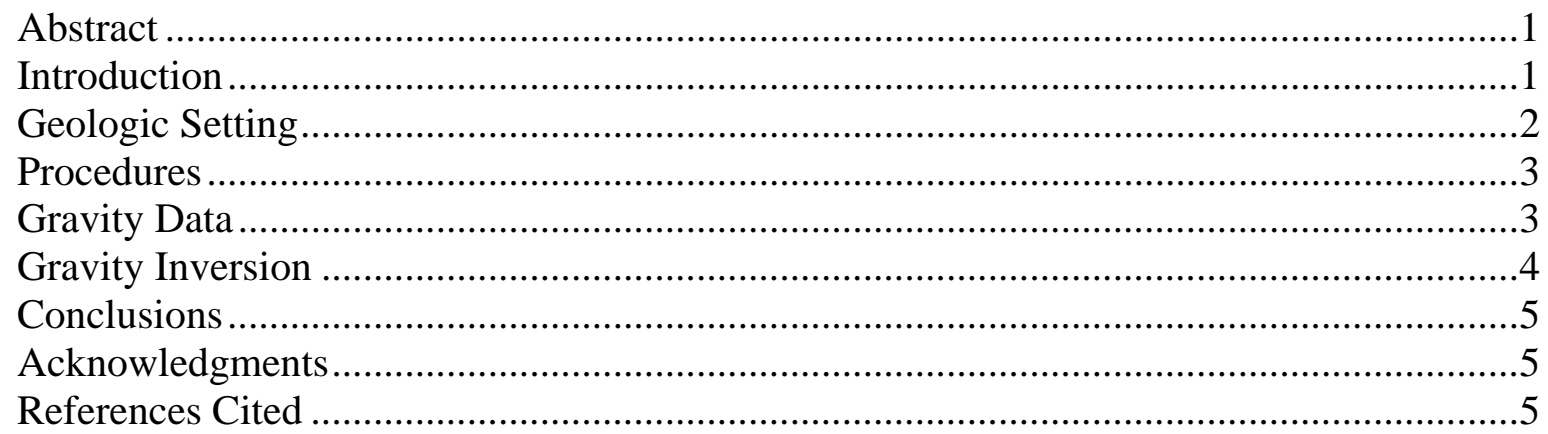

\section{Figures}

1. Shaded-relief map of Newark Valley and vicinity ................................................................ 8

2. Ancient Lake Newark shoreline ………………………………………………....

3. Locations of gravity stations (A) previously available, and (B) those added during the

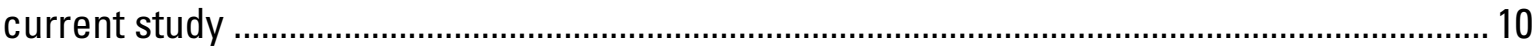

4. Isostatic gravity field (A) using previously available stations, and (B) including stations added during the current study

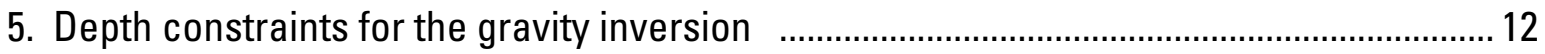

6. Depth to pre-Cenozoic basement ................................................................................... 13

7. Cross-section showing depth-to-basement …………………………………………....14

\section{Tables}

1. Principal facts of gravity stations, Newark Valley, Nevada ................................................. 15

2. Cenozoic density-depth function for the Newark Valley study area.................................. 18 


\title{
Gravity Data from Newark Valley, White Pine County, Nevada
}

\author{
By Edward A. Mankinen and Edwin H. McKee'
}

\begin{abstract}
The Newark Valley area, eastern Nevada is one of thirteen major ground-water basins investigated by the BARCAS (Basin and Range Carbonate Aquifer Study) Project. Gravity data are being used to help characterize the geophysical framework of the region. Although gravity coverage was extensive over parts of the BARCAS study area, data were sparse for a number of the valleys, including the northern part of Newark Valley. We addressed this lack of data by establishing seventy new gravity stations in and around Newark Valley. All available gravity data were then evaluated to determine their reliability, prior to calculating an isostatic residual gravity map to be used for subsequent analyses. A gravity inversion method was used to calculate depths to pre-Cenozoic basement rock and estimates of maximum alluvial/volcanic fill. The enhanced gravity coverage and the incorporation of lithologic information from several deep oil and gas wells yields a view of subsurface shape of the basin and will provide information useful for the development of hydrogeologic models for the region.
\end{abstract}

\section{Introduction}

Enabling legislation and funding for the BARCAS study was through HR 4593, the "Lincoln County Conservation, Recreation, and Development Act of 2004." The specific language in the bill that relates to the study directs the Secretary of Interior, acting through the United States Geological Survey and the Desert Research Institute, and a designee from the State of Utah to conduct a study to investigate ground water quantity, quality, and flow characteristics in the deep carbonate and alluvial aquifers of Lincoln and White Pine Counties, Nevada and adjacent areas in Utah. A draft report of this study is currently available (Welch and Bright, 2007).

The Geophysical Unit of Menlo Park (GUMP) initiated a number of geophysical investigations within valleys encompassed by the BARCAS study where data were lacking. Surface geophysical techniques were applied to take advantage of characteristic density and magnetic properties of different rocks to provide insight into the subsurface geology and identify faults, subsurface structure, and the interconnectivity of adjacent basins. Geophysical results were summarized in a chapter of the BARCAS draft report (Sweetkind and others, 2007), but detailed interpretations and the physical data are appearing in separate releases (e.g., Watt and Ponce, 2007). This paper contains new gravity data from Newark Valley.

Menlo Park, Calif. 


\section{Geologic Setting}

The main part of Newark Valley is bounded on the west by the Diamond Mountains, and Buck Mountain and other bedrock areas to the east (figure 1). At its southern end, Newark Valley is divided into two parts, separated by the Pancake Range. The area shown in figure 1, herein referred to as the study area, constitutes part of the Newark Valley ground-water system, one of thirty-nine regional flow systems of the Great Basin (Harrill and Prudic, 1998). The Newark Valley system covers an area of $\sim 3,760 \mathrm{~km}^{2}$ $\left(1,450 \mathrm{mi}^{2}\right)$ and receives $\sim 27$ hectometers ${ }^{3}(22,000$ acre-feet) of recharge per year (Harrill and Prudic, 1998).

The oldest rocks in the study area belong to the Lower Cambrian Prospect Mountain Quartzite exposed in the Diamond Mountains (Lehner and others, 1961; Hose and others, 1976). Where not greatly faulted and fractured, these rocks form effective barriers to ground-water flow especially where they are in contact with younger carbonate rocks, and they may form the base of the carbonate-rock aquifer in areas where circulation extends throughout the entire stratigraphic thickness (Plume, 1996; Harrill and Prudic, 1998). The carbonate-rock aquifer is a thick sequence of predominately carbonate formations overlying the quartzite and ranging in age from the Middle Cambrian to Lower Triassic (Hose and others, 1976; Plume, 1996). The total stratigraphic thickness of the carbonate sequence in the study area is $\sim 4,000$ meters (Plume, 1996).

Overlying the carbonate sequence in the study area is the Cretaceous Newark Canyon Formation (Lehner and others, 1961; Hose and others, 1976), a sequence of continental deposits exposed mainly in the Diamond Mountains and, perhaps, in the Pancake Range (Hose and others, 1976). Other rocks that we consider part of the preCenozoic basement in the study area are a series of shallow intrusive rocks (Hose and others, 1976; Stewart and Carlson, 1978) ranging from Jurassic to Tertiary in age. All, regardless of age, are grouped with the basement rocks because their density is similar to most of the pre-Cenozoic rocks and differs strongly from that of the later eruptive and basin-fill rocks. Intrusive igneous rocks typically are barriers to ground-water flow (Plume, 1996) except in areas where extensively fractured.

Major extensional faulting began throughout the region at about $17 \mathrm{Ma}$ (McKee, 1971; Christiansen and McKee, 1978; Stewart, 1978) and formed the horst-graben terrain that is typical of the Basin and Range Province. Clastic material derived from adjacent mountain ranges began filling the basins, including semi-consolidated to unconsolidated sand, gravel, silt, clay, and local evaporites with some interbedded volcanic units in many areas. None of the oil and gas wells drilled in Newark Valley differentiate between the various basin-fill units, so whether volcanic rocks occur is unknown. Existing aeromagnetic data for the study area (e.g., Hildenbrand and Kucks, 1988; Watt and Ponce, 2007) are generally of poor quality and insufficient for resolving shallow magnetic sources. The sand and gravel deposits form a major, shallow aquifer in the region where they are not clogged by clay or zeolitic intergranular materials. These aquifers are commonly exploited because groundwater in the valleys typically is within a few meters or tens of meters below the ground surface and easily reached by wells. During Pleistocene time, ancient Lake Newark filled the main part of Newark Valley and the area west of the Pancake Range to a shoreline altitude of 1847 meters (Reheis, 1999) —more than 70 meters above the current lake levels (figure 2). 


\section{Procedures}

Gravity data were obtained using LaCoste and Romberg meters (G17C and G8N) and observed gravity values were referenced to the base station at the Ely, Nevada airport $(\boldsymbol{E} \boldsymbol{L Y A})$, at $39^{\circ} 17.59^{\prime} \mathrm{N},-114^{\circ} 50.52^{\prime} \mathrm{W}$. This station is tied to the International Gravity Standardization Net 1971 (ISGN 71) gravity datum (Morelli, 1974) and has an observed gravity value of $979,480.08 \mathrm{mGal}$. Locations of gravity stations were determined with a differential Global Positioning Satellite (GPS) system using differential corrections provided by Continually Operated Reference Station (CORS) satellites. Locations after post-acquisition processing are accurate to within 1 meter, both horizontally and vertically.

\section{Gravity Data}

Seventy new gravity stations were established in the area of Newark Valley during 2005 and 2006 (figure 3b). Observed gravity at each station was adjusted by assuming a time-dependent linear drift between readings of a base station at the start and finish of each daily survey. This adjustment compensates for drift in the instrument's spring. Observed gravity values are considered accurate to about $0.05 \mathrm{mGal}$ based on repeat measurements over several mountain calibration loops (Barnes and others, 1969; Ponce and Oliver, 1981). Gravity data were reduced using standard gravity corrections (Blakely, 1995) and a reduction density of $2670 \mathrm{~kg} / \mathrm{m}^{3}$. Field terrain corrections (zones A and B of Hayford and Bowie, 1912) were carried out to $68 \mathrm{~m}$ using templates and charts (e.g., Plouff, 2000). Inner-zone terrain corrections for zones C and D (Hayford and Bowie, 1912), which are necessary to account for variations in topography near a gravity station, were obtained to a radial distance of $2 \mathrm{~km}$ using digitized topography in a digital elevation model (DEM) (D. Plouff, USGS, written communication, 2006). Outer terrain corrections, from $2 \mathrm{~km}$ to 167 $\mathrm{km}$, are also calculated using digitized topography and a procedure by Plouff (1977). The resulting gravity anomaly is termed the complete Bouguer anomaly.

A regional isostatic field was calculated using an Airy-Heiskanen (Heiskanen and Vening Meinesz, 1958) model for local compensation of topographic loads (Jachens and Roberts, 1981; Simpson and others, 1986). This model assumes a crustal thickness of 25 $\mathrm{km}$, a crustal density of $2670 \mathrm{~kg} / \mathrm{m}^{3}$, and a $400 \mathrm{~kg} / \mathrm{m}^{3}$ density contrast between the crust and mantle. This regional isostatic field was subtracted from the complete Bouguer anomaly, thus removing long-wavelength variations in the gravity field that are inversely related to topography. The resulting isostatic residual gravity anomaly, therefore, is a reflection of local density distributions within the middle to upper crust. Gravity data obtained during the course of this study, and their associated parameters, are given in table 1 and are available via download as an Excel spreadsheet.

Because prior gravity data (figure 3a) for the study area were made by many different observers at different times (see compilation of Ponce, 1997), we examined the dataset to remove duplicate and inconsistent entries. In order to reduce edge effects in the grids we will produce, the area examined is larger than the study area (figure 1) and extends from latitude $39^{\circ} 0^{\prime}$ to $40^{\circ} 20^{\prime}$ and from $-115^{\circ} 10^{\prime}$ to $-116^{\circ} 10^{\prime}$.

After removing duplicate entries, we then compared reported station elevations with elevations interpolated from 10- and 30-meter DEMs using a procedure by D. Plouff (USGS, written communication, 2005). We flagged differences greater than 24 meters as 
indicating possible errors in station location or elevation, and each station identified was examined individually to confirm the discrepancy. Some of these errors occurred because of imprecise locations (i.e., lack of significant digits in published reports) and could be corrected with a high degree of confidence. Where the source of the discrepancy could not be determined and corrected (22 stations total), that station was omitted from the dataset. Observations from the revised dataset were then gridded at a spacing of $0.5 \mathrm{~km}$ using the minimum curvature algorithm of Webring (1981), and the resulting isostatic residual gravity field (fig. 4b) is considered reliable for subsequent analyses.

\section{Gravity Inversion}

To first order, the isostatic residual gravity field (fig. 4) reflects the pronounced contrast between dense $(2670 \mathrm{~kg} / \mathrm{m} 3)$ pre-Cenozoic basement rocks and the significantly less dense (generally $<2500 \mathrm{~kg} / \mathrm{m} 3$ ) overlying volcanic and sedimentary basin-fill. Because of this relationship, the gravity inversion method (Jachens and Moring, 1990) can be used to separate the isostatic residual anomaly into pre-Cenozoic "basement" and Cenozoic "basin" fields, thus allowing an estimate of thickness of Cenozoic alluvial fill within the area. The accuracy of thickness estimates derived by the gravity inversion technique is dependent on the assumed density-depth relation of the Cenozoic rocks, and on the initial density assigned to the basement rocks. Density of basement rocks is generally assumed to be $2670 \mathrm{~kg} / \mathrm{m} 3$ and this value is considered appropriate in this area where major exposures consist of late Precambrian through late Paleozoic marine carbonate and quartzose sedimentary rocks.

The density of basin-filling deposits generally increases with the degree of compaction and consolidation, and thus usually correlates with depth of burial, as well as with other factors such as increasing water content. The density-versus-depth relationship we use is given in table 2 and is the same used by Jachens and Moring (1990) to separate the isostatic residual anomaly into basement and basin fields. This density-depth distribution also is the same as used by Saltus and Jachens (1995) for their basin-depth map of the Basin and Range Province and similar to those shown to be widely applicable to other volcanic basin-fill deposits throughout Nevada (Blakely and others, 1998, 2000; Mankinen and others, 2003).

In the inversion process, the density of basement is allowed to vary horizontally but the density of basin-filling deposits is fixed using the density-depth distribution (table 2). In this iterative approach, a first approximation of the basement gravity field is derived from those gravity measurements made on exposed pre-Cenozoic rocks. A modified version of the inversion method used here (B.A. Chuchel, unpublished data, 2005) allows basement gravity values to be approximated by correcting the isostatic gravity anomaly at sites where depth to basement is known from deep boreholes (Garside and others, 1988; Hess, 2004). Information on oil and gas wells for Nevada is available on-line at http://www.nbmg.unr.edu/lists/oil/oil.htm. Wells providing constraints in the Newark Valley region are shown in figure 5. This basement gravity field ignores the gravity effects of nearby basins and is subtracted from the observed gravity, which provides the first approximation of the basin gravity field. Again using the selected density-depth relation, the thickness of the basin-filling deposits is calculated. The gravitational effect of this first approximation of the basin-filling layer is computed at each known basement station. This effect is, in turn, subtracted from the first approximation of the basement 
gravity field, and the process is repeated until successive iterations produce no substantial changes in the basement gravity field. Results of the inversion, shown in figure 6, were gridded at a spacing of $2.0 \mathrm{~km}$ using a minimum curvature algorithm Webring (1981).

\section{Conclusions}

New gravity data collected during the course of this study allows a much improved definition of the Newark Valley basin. A comparison of the gravity anomaly field before and after the current study (figure 4) shows that the low-density, basin-fill is much more continuous through the main part of Newark Valley and into Huntington Valley than previously known. The main part of Newark Valley is separated from the area southwest of the Pancake Range by a bedrock sill near Pancake summit (figure 7). Another bedrock sill separates Newark Valley from Huntington Valley near the topographic rise between the two valleys. Two oil and gas wells in this vicinity (figure 4) encountered bedrock at depths of 150 and 330 meters below the surface. Thickness of fill throughout much of Newark Valley is generally between 1 and $2 \mathrm{~km}$ (figure 7), with a maximum approaching 4 $\mathrm{km}$ in limited areas. It is possible, however, that the apparent rise in the basement surface near the center of the valley may not be as pronounced as shown because there is a lack of gravity observations due to present-day Newark Lake.

\section{Acknowledgments}

This study was performed with the support of the BARCAS (Basin and Range Carbonate Aquifer Study) Project. Reviews by C.W. Roberts and J.T. Watt helped to clarify and improve the manuscript.

\section{References Cited}

Barnes, D.F., Oliver, H.W., and Robbins, S.L., 1969, Standardization of gravimeter calibrations in the Geological Survey: Eos, Transactions of the American Geophysical Union, v. 50, p. 526-527.

Blakely, R.J., 1995, Potential Theory in Gravity and Magnetic Applications: Cambridge University Press, $441 \mathrm{p}$.

Blakely, R.J., Langenheim, V.E., Ponce, D.A., and Dixon, G.L., 2000, Aeromagnetic survey of the Amargosa Desert, Nevada and California: A tool for understanding near-surface geology and hydrology: U.S. Geological Survey Open-File Report 00-188, 35 p.

Blakely, R.J., Morin, R.L., McKee, E.H., Schmidt, K.M., Langenheim, V.E., and Dixon, G.L., 1998, Three-dimensional model of Paleozoic basement beneath Amargosa Desert and Pahrump Valley, California and Nevada: Implications for tectonic evolution and water-resources: U.S. Geological Survey Open-File Report 98-496, 27 p.

Christiansen, R.L., and McKee, E.H., 1978, Late Cenozoic volcanic and tectonic evolution of the Great Basin and Columbia Intermontane regions, in Smith, R.B., and Eaton, G.P., eds., Cenozoic tectonics and regional geophysics of the Western Cordillera: Geological Society of America Memoir 152, p. 283311. 
Garside, L.J., Hess, R.H., Fleming, K.L., and Weimer, B.S., 1988, Oil and gas developments in Nevada: Nevada Bureau of Mines and Geology Bulletin 104 (on-line database, updated June, 2004).

Harrill, J.R., and Prudic, D.E., 1998, Aquifer systems in the Great Basin region of Nevada, Utah, and adjacent states-Summary report: U.S. Geological Survey Professional Paper 1409-A, 66 p.

Hayford, J.F., and Bowie, William, 1912, The effect of topography and isostatic compensation upon the intensity of gravity: U.S Coast and Geodetic Survey Special Publication 10, $132 \mathrm{p}$.

Heiskanen, W.A., and Vening Meinesz, F.A., 1958, The Earth and its Gravity Field: New York, McGraw-Hill, 470 p.

Hess, R.H., 2004, Nevada oil and gas well database (NVOILWEL): Nevada Bureau of Mines and Geology Open-File Report 04-1, 288 p.

Hildenbrand, T.G., and Kucks, R.P., 1988, Total intensity magnetic anomaly map of Nevada: Nevada Bureau of Mines and Geology Map 93A, scale $1: 750,000$.

Hose, R.K., Blake, M.C., Jr., and Smith, R.M., 1976, Geology and mineral resources of White Pine County, Nevada: Nevada Bureau of Mines and Geology Bulletin 85, 105 p.

Jachens, R.C., and Moring, B.C., 1990, Maps of the thickness of Cenozoic deposits and the isostatic residual gravity over basement for Nevada: U.S. Geological Survey Open-File Report 90-404, 15 p.

Jachens, R.C., and Roberts, C.W., 1981, Documentation of program, ISOCOMP, for computing isostatic residual gravity: U.S. Geological Survey Open-File Report 81-574, 26 p.

Lehner, R.E., Tagg, K.M., Bell, M.M. and Roberts, R.J., 1961, Preliminary geologic map of Eureka County, Nevada: U.S. Geological Survey Miscellaneous Field Studies Map MF-178, scale 1:200,000.

Mankinen, E.A., Hildenbrand, T.G., Fridrich, C.J., McKee, E.H., and Schenkel, C.J., 2003, Geophysical setting of the Pahute Mesa-Oasis Valley region, southern Nevada: Nevada Bureau Mines and Geology Report 50, CDROM, $45 \mathrm{p}$.

McKee, E.H., 1971, Tertiary igneous chronology of the Great Basin of western United States-Implications for tectonic models: Geological Society of America Bulletin, v. 82, p. 3497-3502.

Morelli, C., ed., 1974, The International Gravity Standardization Net 1971: International Association of Geodesy Special Publication 4, $194 \mathrm{p}$.

Plouff, Donald, 1977, Preliminary documentation for a FORTRAN program to compute gravity terrain corrections based on topography digitized on a geographic grid: U.S. Geological Survey Open-File Report 77-535, 45 p.

Plouff, Donald, 2000, Field estimates of gravity terrain corrections and Y2Kcompatible method to convert from gravity readings with multiple base stations to tide- and long-term drift-corrected observations: U.S. Geological Survey Open-File Report 00-140, 37 p. 
Plume, R.W., 1996, Hydrogeologic framework of the Great Basin region of Nevada, Utah and adjacent states: U.S. Geological Survey Professional Paper 1409-B, $64 \mathrm{p}$.

Ponce, D.A., and Oliver, H.W., 1981, Charleston Peak gravity calibration loop, Nevada: U.S. Geological Survey Open-File Report 81-985, 20 p.

Ponce, D.A., 1997, Gravity data of Nevada: U.S. Geological Survey Digital Data Series DDS-42, CD-ROM, $27 \mathrm{p}$.

Reheis, M., 1999, Extent of Pleistocene lakes in the western Great Basin: U.S. Geological Survey Miscellaneous Field Studies Map MF-2323, scale $1: 800,000$.

Saltus, R.W., and Jachens, R.C., 1995, Gravity and basin-depth maps of the Basin and Range Province, western United States: U.S. Geological Survey Geophysical Investigations Map GP-1012, scale 1:2,500,000.

Simpson, R.W., Jachens, R.C., Blakely, R.J., and Saltus, R.W., 1986, A new isostatic residual gravity map of the conterminous United States, with a discussion of the significance of the isostatic residual anomalies: Journal of Geophysical Research, v. 91, p. 8348-8372.

Stewart, J.H., 1978, Basin-range structure in western North America: A review, in Smith, R.B., and Eaton, G.P., eds., Cenozoic tectonics and regional geophysics of the Western Cordillera: Geological Society of America Memoir 152, p. 1-31.

Stewart, J.H., and Carlson, J.E., 1978, Geologic Map of Nevada: U.S. Geological Survey, scale 1:500,000.

Sweetkind, D.S., Knochenmus, L., Ponce, D.A., Wallace, A., Scheirer, D., Watt, J.T., and Plume, R.W., 2007, Hydrogeologic framework, in Welch, A.H., and Bright, D.J., eds., Water resources of the Basin and Range carbonate-rock aquifer system, White Pine County, Nevada, and adjacent areas in Nevada and Utah-Draft report: U.S. Geological Survey Open-File Report 20071156, p. 13-40.

Watt, J.T., and Ponce, D.A., 2007, Geophysical framework investigations influencing ground-water resources in east-central Nevada and west-central Utah, with a section on Geologic and geophysical basin-by-basin descriptions by Wallace, A.R. , Watt, J.T., and Ponce, D.A.: U.S. Geological Survey Open-File Report 2007-1163, 43 p., 2 plates, scale $1: 750,000$.

Webring, M., 1981, MINC, -A gridding program based on minimum curvature: U.S. Geological Survey Open-File Report 81-1224, 43 p.

Welch, A.H., and Bright, D.J., editors, 2007, Water resources of the Basin and Range carbonate-rock aquifer system, White Pine County, Nevada, and adjacent areas in Nevada and Utah-Draft Report: U.S. Geological Survey Open-File Report 2007-1156, 102 p. 

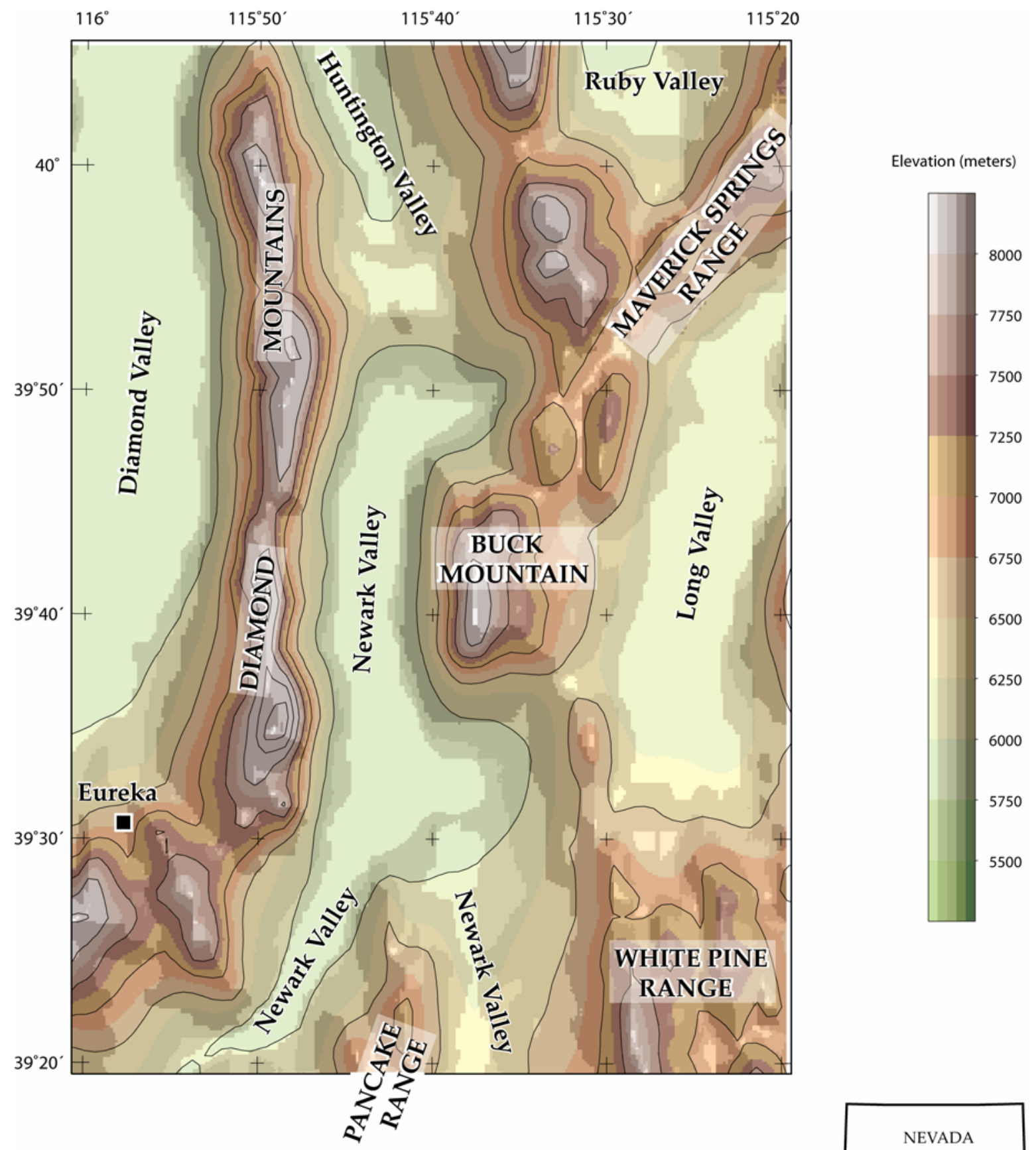

Figure 1. Shaded-relief map of Newark Valley and vicinity. Index map shows location of study area. Topographic contour

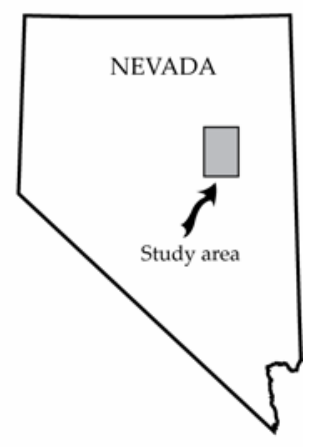
interval $=500 \mathrm{~m}$. 


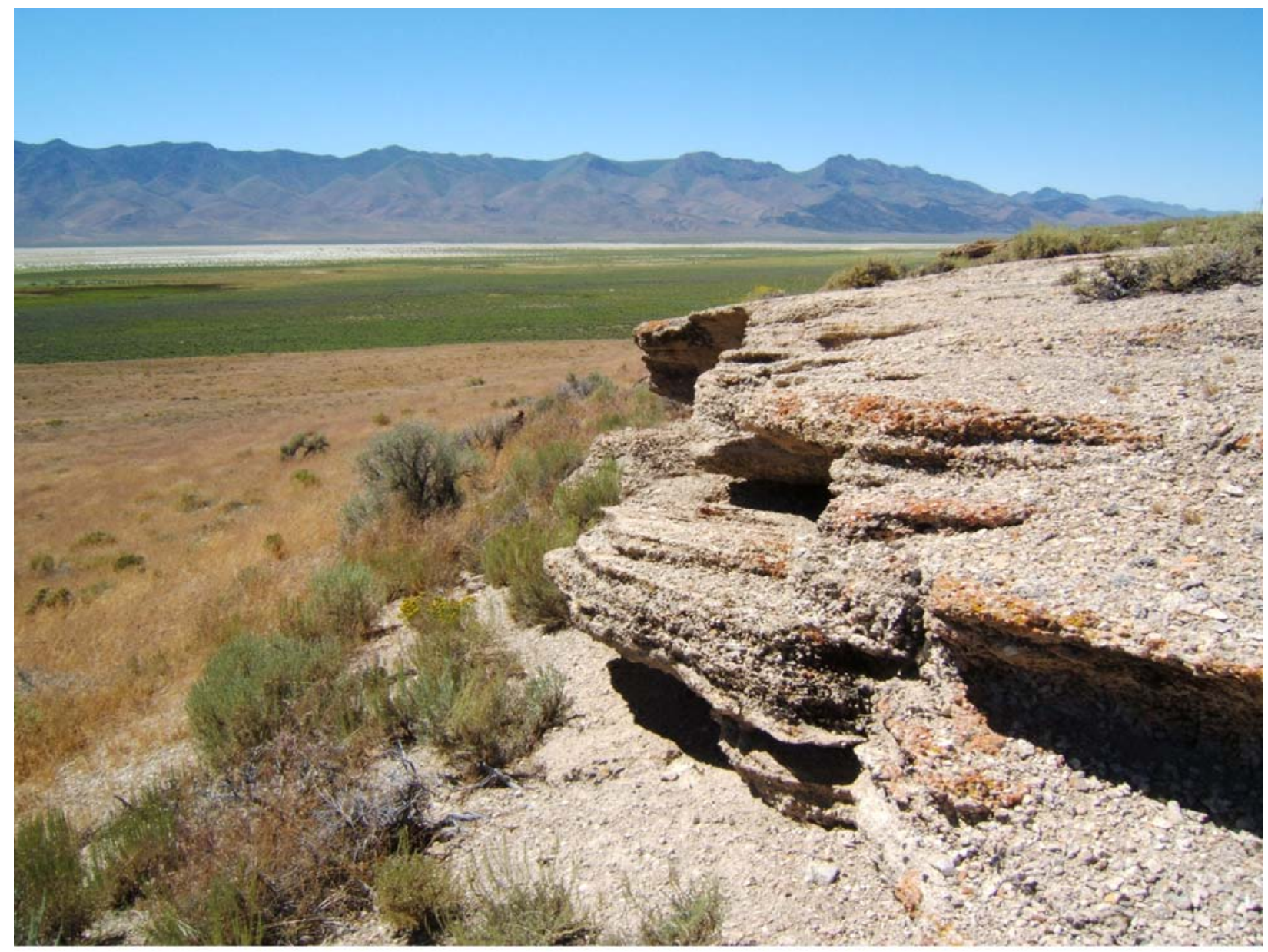

Figure 2. Remnant of ancient Lake Newark shoreline. View looking west toward the Diamond Mountains. Present-day lake surface represented by the playa seen in the middle distance. 


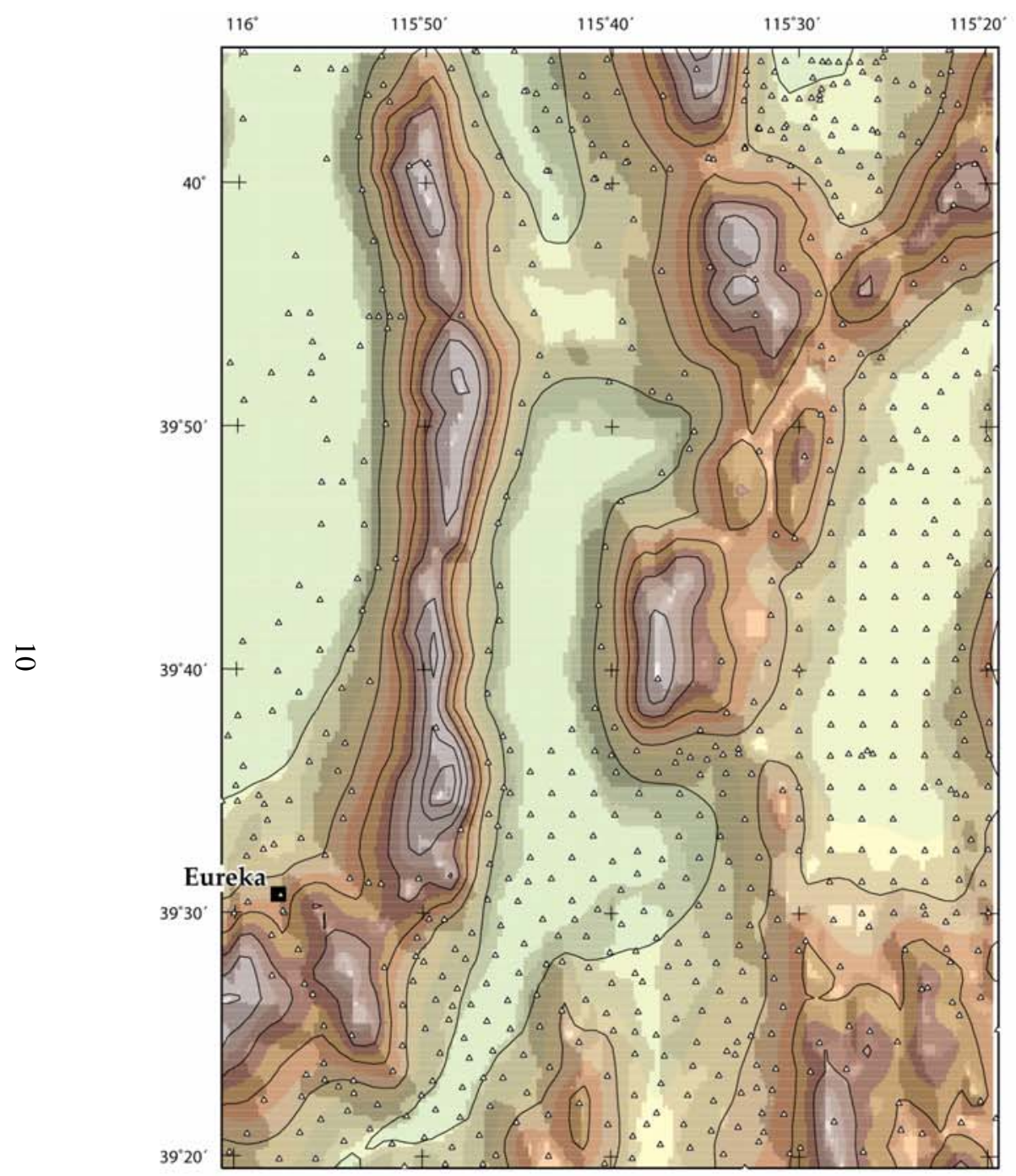

(A)

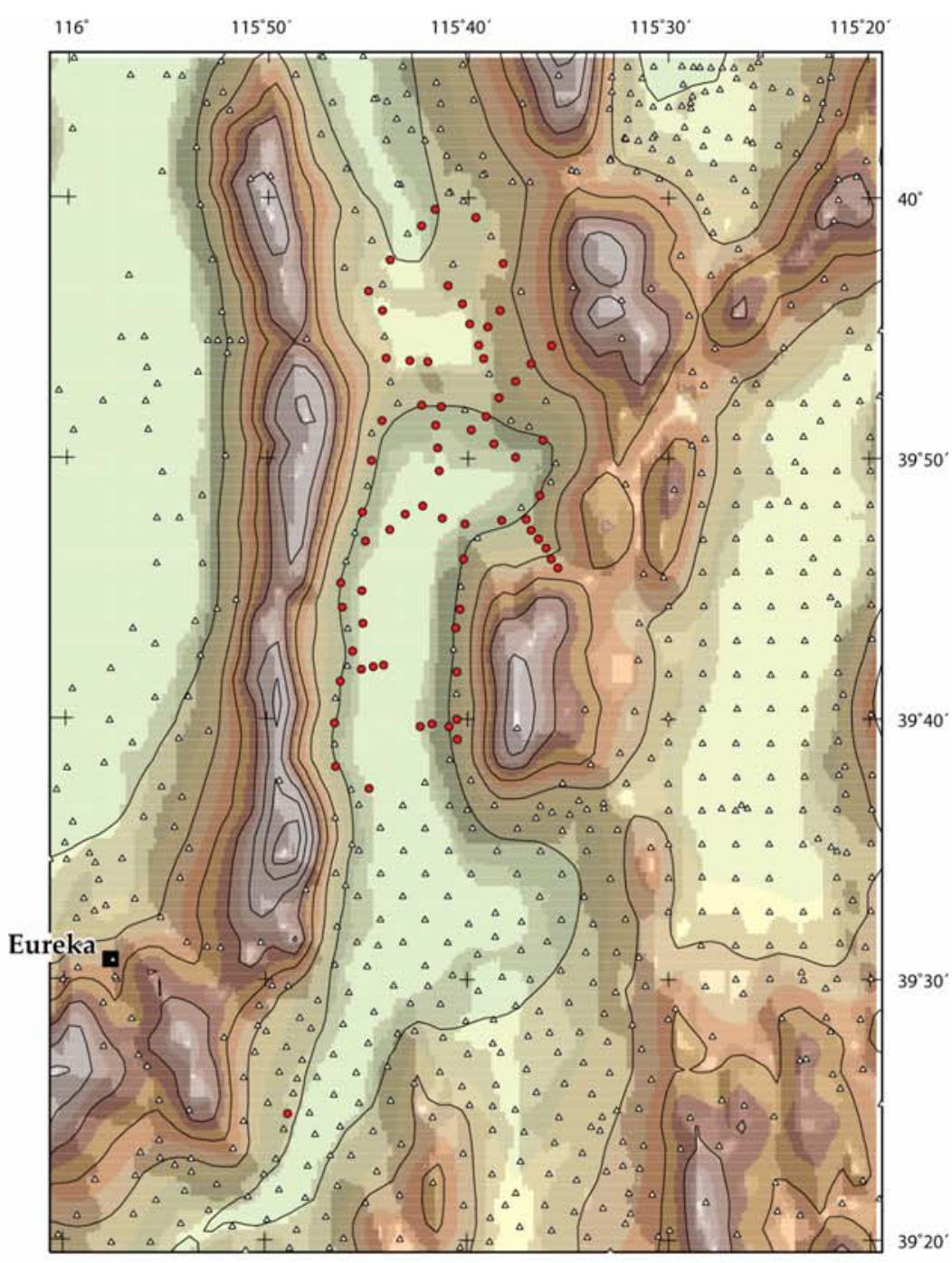

(B)

Figure 3. Locations of gravity stations in the study area. (A) Triangles, previously available stations; (B) Red dots, stations added during the current study. 


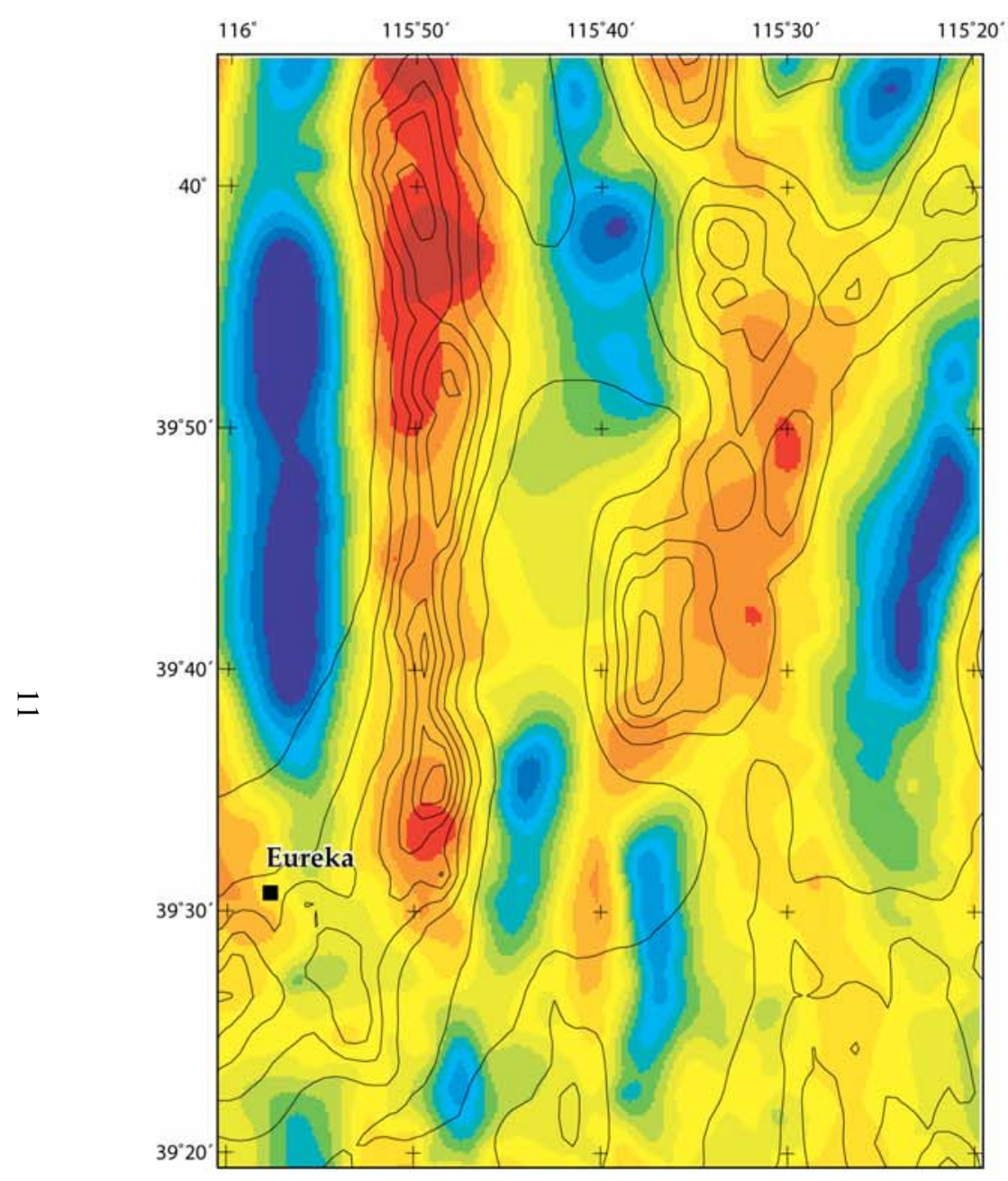

(A)

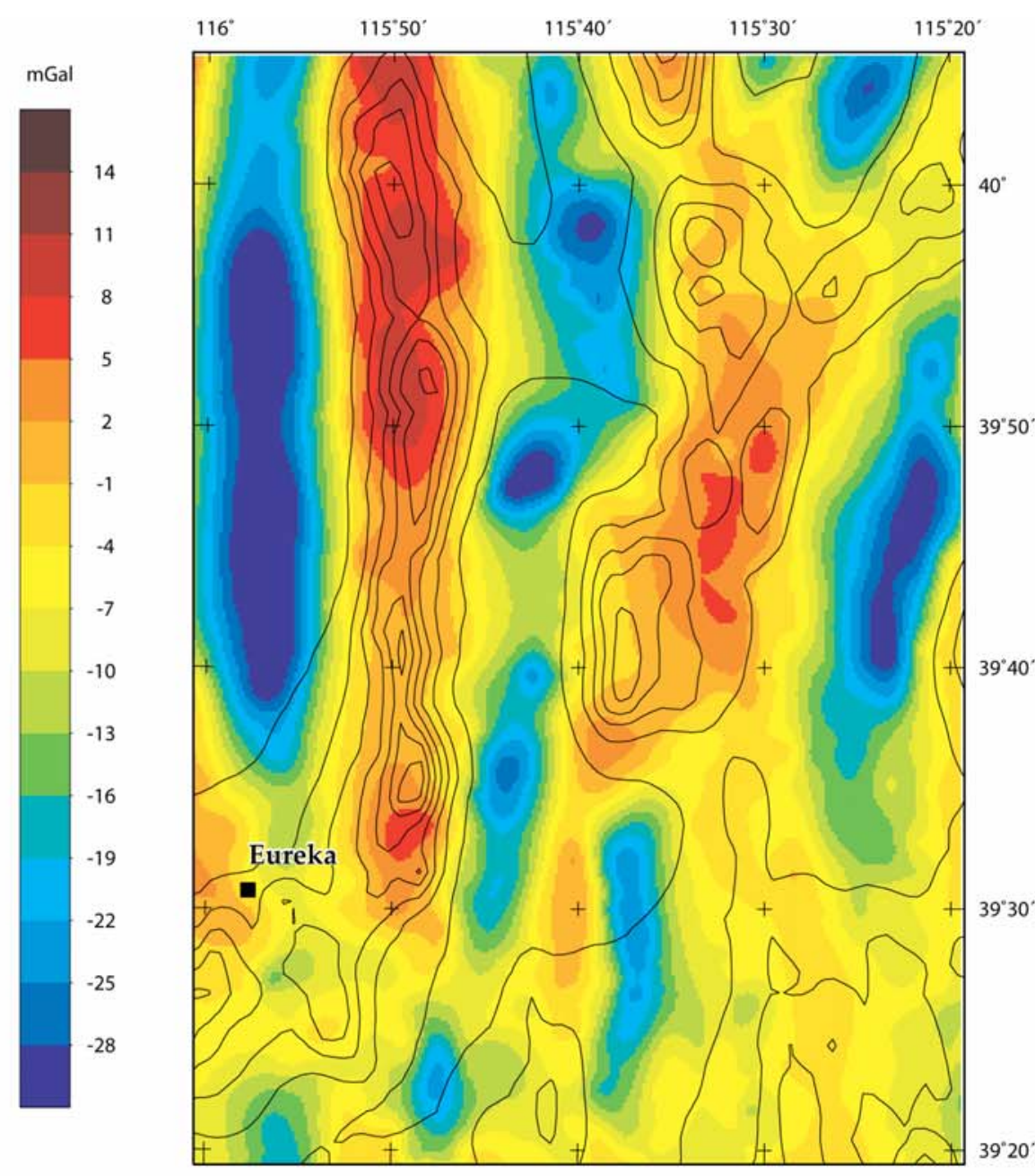

(B)

Figure 4. Isostatic gravity field of the study area. Calculated (A) using previously available gravity stations, and $(B)$ using gravity stations added during the current study. 


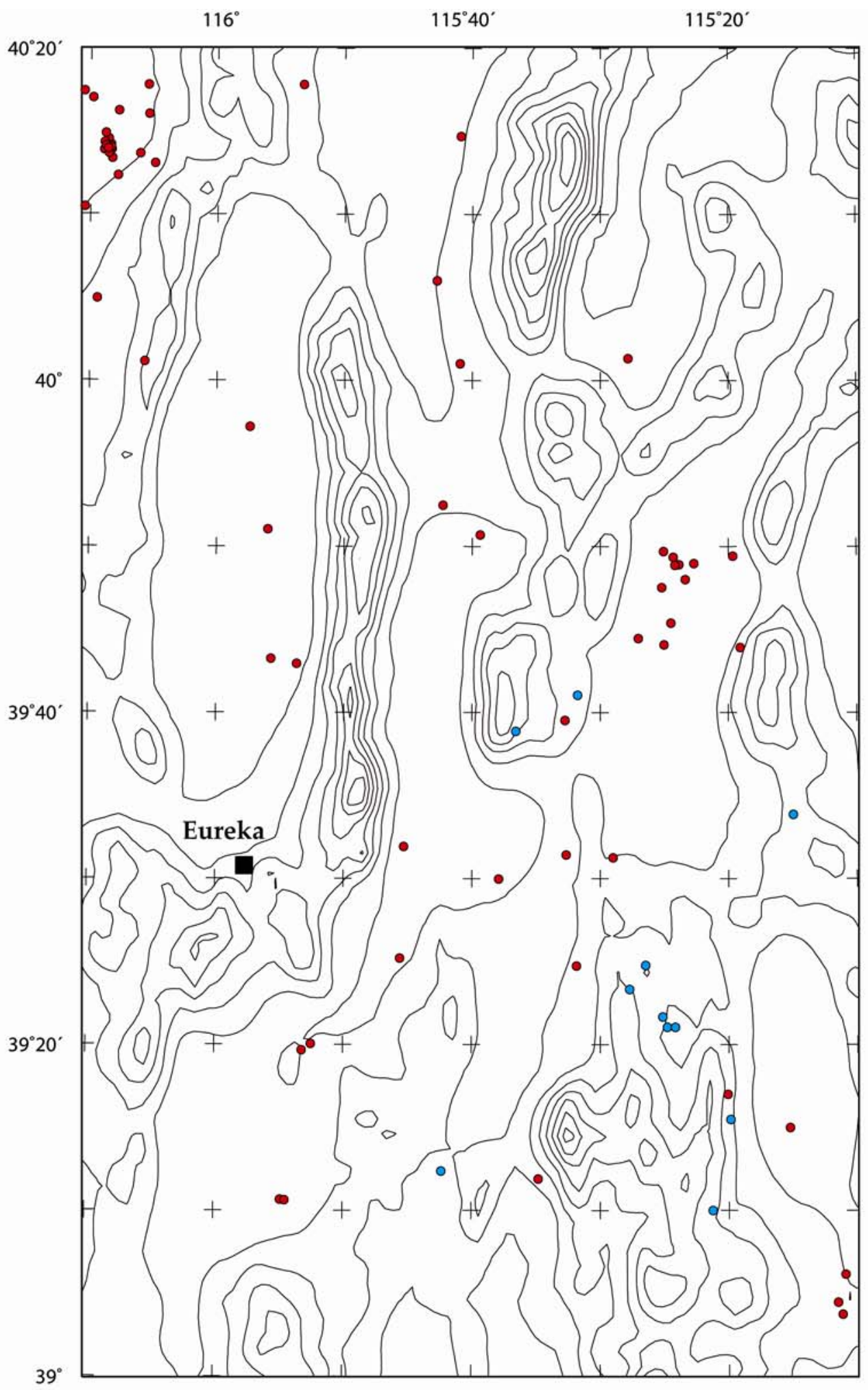

Figure 5. Deep oil and gas wells that are used as constraints in the calculation of the basement surface. Red dots, wells encountering pre-Cenozoic basement; Blue dots, wells spudded in pre-Cenozoic rocks. 


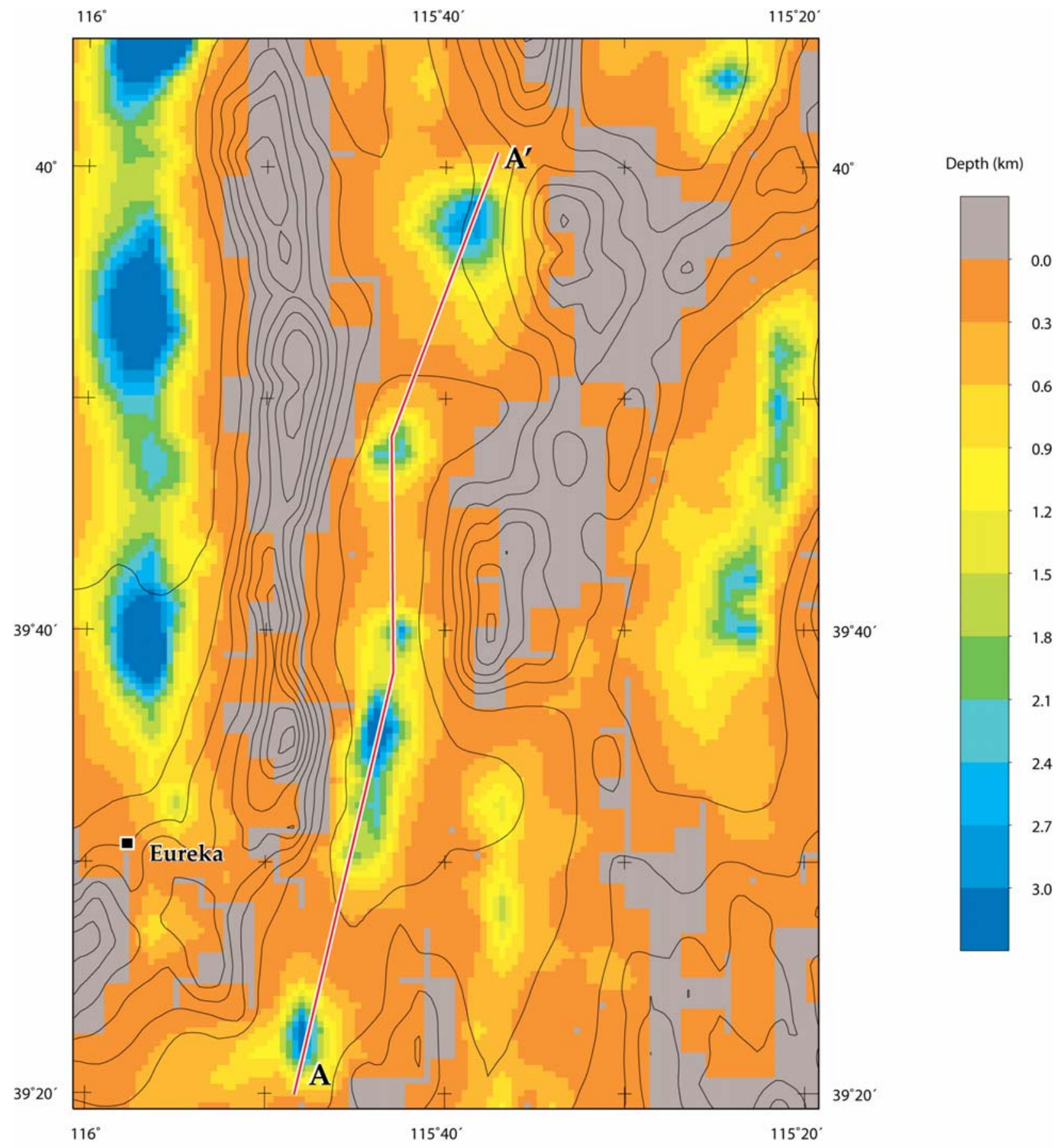

Figure 6. Depth to pre-Cenozoic basement calculated using the gravity inversion method of Jachens and Moring (1990) and incorporating the drill-hole constraints shown in Figure 4. Red line shows location of cross-section shown in Figure 7. 


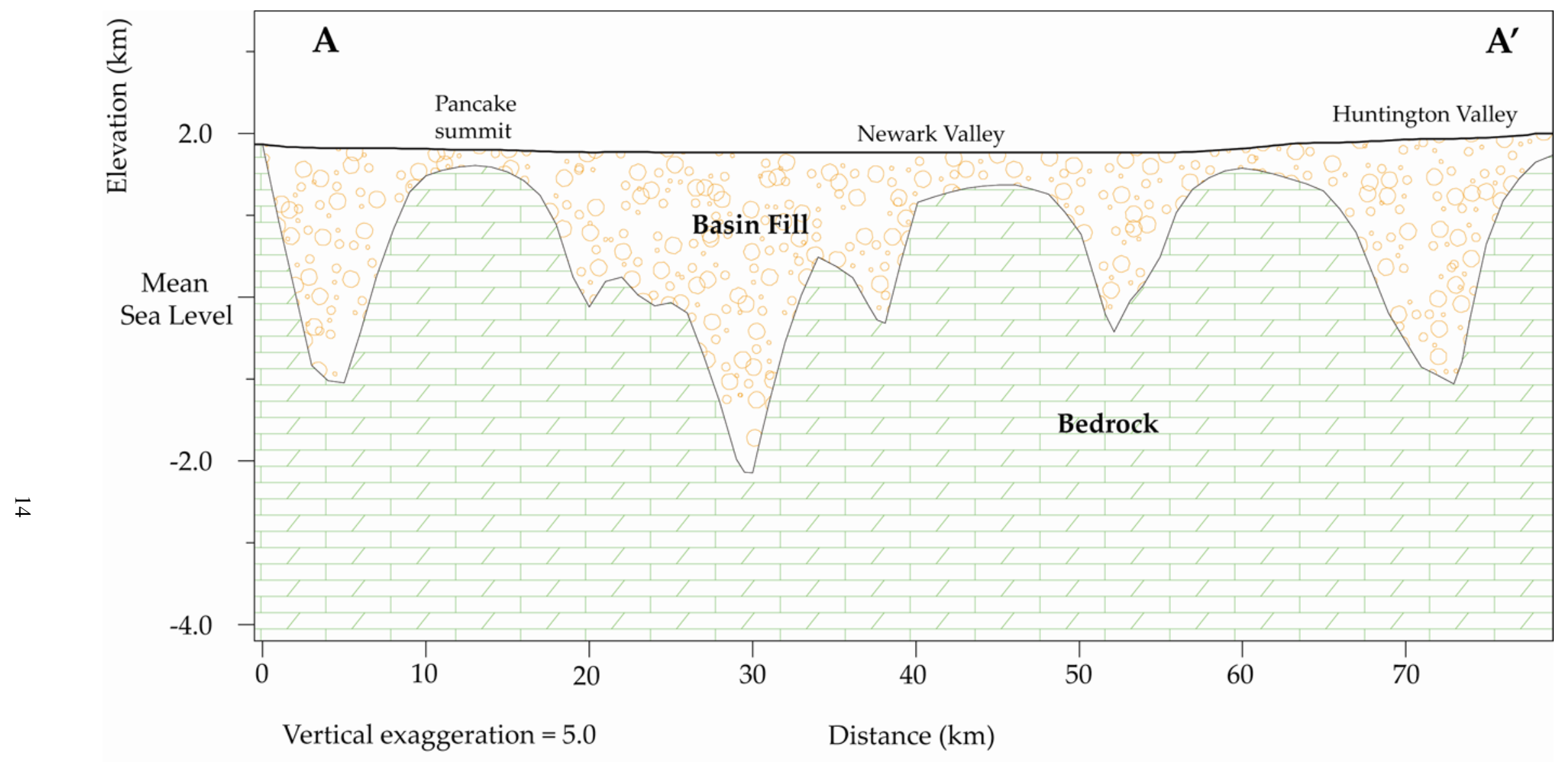

Figure 7. Cross-section along the profile A-A' shown in figure 6 using depths to pre-Cenozoic basement as determined by the gravity inversion method. 
Table 1. Principal facts of new gravity stations from Newark Valley, NV

[Station coordinates, NAD27; elevations, NAVD29; Bouguer anomaly calculated using a reduction density of $2670 \mathrm{~kg} / \mathrm{m}^{3}$; terrain corrections calculated out to $166.7 \mathrm{~km}$ ]

\begin{tabular}{|c|c|c|c|c|c|c|c|c|}
\hline $\begin{array}{c}\text { Station } \\
\text { ID }\end{array}$ & $\begin{array}{l}\text { Long. } \\
\left({ }^{\circ} \mathrm{W}\right)\end{array}$ & $\begin{array}{l}\text { Lat. } \\
\left({ }^{\circ} \mathbf{N}\right)\end{array}$ & $\begin{array}{c}\text { Elev. } \\
\text { (meters) }\end{array}$ & $\begin{array}{c}\text { Obs. } \\
\text { Gravity } \\
\text { (mGal) }\end{array}$ & $\begin{array}{c}\text { Free Air } \\
\text { Anomaly } \\
\text { (mGal) }\end{array}$ & $\begin{array}{c}\text { Total } \\
\text { TC } \\
\text { (mGal) }\end{array}$ & $\begin{array}{c}\text { Bouguer } \\
\text { Anomaly } \\
\text { (mGal) }\end{array}$ & $\begin{array}{c}\text { Isostatic } \\
\text { Anomaly } \\
\text { (mGal) }\end{array}$ \\
\hline 5NWV001 & -115.8147 & 39.4140 & 1823.0 & 979545.93 & -8.59 & 0.68 & -213.39 & -7.71 \\
\hline 5NWV002 & -115.7758 & 39.6363 & 1801.8 & 979570.42 & -10.42 & 2.84 & -210.68 & -6.34 \\
\hline 5NWV003 & -115.7770 & 39.6642 & 1794.8 & 979576.46 & -8.98 & 2.53 & -208.78 & -4.63 \\
\hline 5NWV004 & -115.7723 & 39.6908 & 1799.2 & 979581.19 & -5.29 & 1.95 & -206.15 & -2.20 \\
\hline 5NWV005 & -115.7622 & 39.7098 & 1789.4 & 979583.08 & -8.11 & 1.37 & -208.44 & -4.57 \\
\hline 5NWV006 & -115.7708 & 39.7380 & 1793.9 & 979586.81 & -5.48 & 1.84 & -205.87 & -2.30 \\
\hline 5NWV007 & -115.7722 & 39.7537 & 1795.7 & 979586.28 & -6.86 & 2.38 & -206.90 & -3.45 \\
\hline 5NWV008 & -115.7518 & 39.7803 & 1782.7 & 979579.86 & -19.65 & 1.71 & -218.90 & -15.45 \\
\hline 5NWV009 & -115.7542 & 39.7988 & 1808.8 & 979582.47 & -10.65 & 2.22 & -212.32 & -9.05 \\
\hline 5NWV010 & -115.7470 & 39.8320 & 1816.2 & 979584.45 & -9.35 & 2.58 & -211.48 & -8.42 \\
\hline 5NWV011 & -115.7382 & 39.8573 & 1831.5 & 979585.87 & -5.44 & 1.85 & -210.02 & -7.09 \\
\hline 5NWV012 & -115.7053 & 39.8673 & 1818.0 & 979586.62 & -9.74 & 0.66 & -214.01 & -10.80 \\
\hline 5NWV013 & -115.6892 & 39.8665 & 1818.3 & 979582.73 & -13.46 & 0.52 & -217.91 & -14.53 \\
\hline 5NWV014 & -115.6515 & 39.8603 & 1822.8 & 979577.53 & -16.74 & 0.46 & -221.74 & -17.92 \\
\hline 5NWV015 & -115.6043 & 39.8450 & 1815.7 & 979582.83 & -12.26 & 0.83 & -216.09 & -11.70 \\
\hline 5NWV016 & -115.6072 & 39.8098 & 1809.6 & 979588.77 & -5.07 & 1.27 & -207.78 & -3.20 \\
\hline 5NWV017 & -115.6387 & 39.7937 & 1810.5 & 979585.45 & -6.69 & 0.72 & -210.05 & -5.69 \\
\hline
\end{tabular}




\begin{tabular}{|c|c|c|c|c|c|c|c|c|}
\hline 5NWV018 & -115.6688 & 39.7913 & 1782.9 & 979584.34 & -16.09 & 0.61 & -216.46 & -12.34 \\
\hline 5NWV019 & -115.6878 & 39.7950 & 1781.1 & 979569.90 & -31.42 & 0.51 & -231.69 & -27.76 \\
\hline 5NWV020 & -115.7043 & 39.8030 & 1781.3 & 979565.29 & -36.66 & 0.58 & -236.90 & -33.17 \\
\hline 5NWV021 & -115.7188 & 39.7977 & 1782.9 & 979566.42 & -34.57 & 0.70 & -234.86 & -31.24 \\
\hline 5NWV022 & -115.7313 & 39.7877 & 1784.1 & 979567.42 & -32.33 & 0.85 & -232.60 & -29.03 \\
\hline 5NWV023 & -115.6705 & 39.7690 & 1798.1 & 979584.87 & -8.89 & 1.41 & -210.17 & -5.97 \\
\hline 5NWV024 & -115.6732 & 39.7370 & 1825.0 & 979573.40 & -9.23 & 1.98 & -212.95 & -8.60 \\
\hline 5NWV025 & -115.6768 & 39.7250 & 1813.4 & 979573.05 & -12.09 & 2.03 & -214.46 & -10.07 \\
\hline 5NWV026 & -115.6758 & 39.6968 & 1845.3 & 979564.45 & -8.34 & 2.32 & -214.00 & -9.41 \\
\hline 5NWV027 & -115.6755 & 39.6665 & 1854.0 & 979560.98 & -6.42 & 2.02 & -213.35 & -8.59 \\
\hline 5NWV028 & -115.6820 & 39.6618 & 1812.2 & 979564.67 & -15.21 & 1.65 & -217.83 & -13.04 \\
\hline 5NWV029 & -115.6960 & 39.6635 & 1793.4 & 979563.10 & -22.75 & 1.03 & -223.88 & -19.14 \\
\hline 5NWV030 & -115.7060 & 39.6618 & 1784.0 & 979560.26 & -28.32 & 0.84 & -228.58 & -23.90 \\
\hline 5NWV031 & -115.6750 & 39.6537 & 1855.5 & 979560.02 & -5.80 & 2.02 & -212.90 & -8.05 \\
\hline 5NWV032 & -115.6183 & 39.7943 & 1835.2 & 979580.13 & -4.45 & 0.92 & -210.37 & -5.87 \\
\hline 5NWV033 & -115.6143 & 39.7877 & 1860.3 & 979575.29 & -0.97 & 1.03 & -209.59 & -5.04 \\
\hline 5NWV034 & -115.6082 & 39.7818 & 1889.1 & 979570.58 & 3.72 & 1.21 & -207.95 & -3.35 \\
\hline 5NWV035 & -115.6018 & 39.7760 & 1926.0 & 979565.81 & 10.85 & 1.38 & -204.78 & -0.16 \\
\hline 5NWV036 & -115.5975 & 39.7692 & 1967.8 & 979557.56 & 16.10 & 1.67 & -203.93 & 0.73 \\
\hline 5NWV037 & -115.5918 & 39.7635 & 2028.2 & 979546.30 & 23.98 & 2.08 & -202.40 & 2.27 \\
\hline 5NWV038 & -115.6410 & 39.8722 & 1864.0 & 979565.73 & -16.89 & 0.53 & -226.43 & -22.67 \\
\hline 5NWV039 & -115.6505 & 39.9175 & 1917.9 & 979557.19 & -12.85 & 0.55 & -228.42 & -25.10 \\
\hline 5NWV040 & -115.6657 & 39.9193 & 1896.3 & 979567.36 & -9.49 & 0.45 & -222.74 & -19.59 \\
\hline 5NWV041 & -115.6717 & 39.9322 & 1881.9 & 979568.20 & -14.26 & 0.48 & -225.85 & -22.83 \\
\hline 5NWV042 & -115.6833 & 39.9437 & 1852.7 & 979579.13 & -13.33 & 0.49 & -221.65 & -18.79 \\
\hline 6NWV043 & -115.7482 & 39.6220 & 1777.5 & 979561.09 & -25.96 & 1.34 & -225.00 & -20.34 \\
\hline 6NWV044 & -115.7367 & 39.7012 & 1779.5 & 979574.18 & -19.29 & 0.79 & -219.10 & -14.91 \\
\hline 6NWV045 & -115.7450 & 39.7000 & 1782.4 & 979577.06 & -15.39 & 0.84 & -215.49 & -11.39 \\
\hline
\end{tabular}




\begin{tabular}{lllllllll} 
6NWV046 & -115.7550 & 39.6983 & 1784.1 & 979580.60 & -11.20 & 1.03 & -211.29 & -7.25 \\
6NWV047 & -115.7535 & 39.7277 & 1778.5 & 979579.79 & -16.33 & 1.00 & -215.82 & -11.98 \\
6NWV048 & -115.7547 & 39.7487 & 1781.5 & 979582.31 & -14.76 & 1.26 & -214.33 & -10.65 \\
6NWV049 & -115.6935 & 39.8545 & 1801.7 & 979585.05 & -15.21 & 0.54 & -217.76 & -14.31 \\
6NWV050 & -115.6920 & 39.8400 & 1788.5 & 979581.79 & -21.24 & 0.52 & -222.33 & -18.73 \\
6NWV051 & -115.6907 & 39.8255 & 1783.3 & 979574.88 & -28.47 & 0.50 & -229.01 & -25.34 \\
6NWV052 & -115.6642 & 39.8517 & 1804.0 & 979588.28 & -11.01 & 0.43 & -213.94 & -10.16 \\
6NWV053 & -115.6453 & 39.8427 & 1795.9 & 979581.73 & -19.25 & 0.48 & -221.21 & -17.17 \\
6NWV054 & -115.6273 & 39.8340 & 1792.8 & 979578.97 & -22.22 & 0.58 & -223.73 & -19.52 \\
6NWV055 & -115.7153 & 39.8958 & 1884.8 & 979578.53 & 0.20 & 0.60 & -211.60 & -8.79 \\
6NWV056 & -115.7002 & 39.8953 & 1895.7 & 979576.00 & 1.08 & 0.60 & -211.94 & -8.92 \\
6NWV057 & -115.7350 & 39.8973 & 1909.5 & 979575.81 & 4.96 & 0.87 & -209.34 & -6.78 \\
6NWV058 & -115.7380 & 39.9277 & 1888.6 & 979583.33 & 3.35 & 0.67 & -208.81 & -6.51 \\
6NWV059 & -115.7495 & 39.9403 & 1863.7 & 979591.40 & 2.62 & 0.89 & -206.53 & -4.42 \\
6NWV060 & -115.7318 & 39.9603 & 1832.4 & 979594.68 & -5.55 & 0.62 & -211.46 & -9.31 \\
6NWV061 & -115.7055 & 39.9822 & 1816.7 & 979587.84 & -19.17 & 0.48 & -223.46 & -21.15 \\
6NWV062 & -115.6945 & 39.9927 & 1831.0 & 979581.82 & -21.72 & 0.49 & -227.60 & -25.23 \\
6NWV063 & -115.6607 & 39.9875 & 1882.3 & 979569.56 & -17.68 & 0.57 & -229.24 & -26.49 \\
6NWV064 & -115.6378 & 39.9582 & 1960.6 & 979546.73 & -13.75 & 0.72 & -233.93 & -30.79 \\
6NWV065 & -115.6403 & 39.9280 & 1957.1 & 979547.46 & -11.43 & 0.66 & -231.27 & -27.95 \\
6NWV066 & -115.6580 & 39.9058 & 1886.7 & 979569.36 & -9.25 & 0.46 & -221.41 & -18.04 \\
6NWV067 & -115.6537 & 39.8972 & 1873.3 & 979570.00 & -11.97 & 0.52 & -222.57 & -19.06 \\
6NWV068 & -115.6272 & 39.8828 & 1923.5 & 979553.56 & -11.67 & 0.68 & -227.72 & -23.96 \\
6NWV069 & -115.6145 & 39.8940 & 1993.4 & 979545.51 & 0.85 & 0.96 & -222.77 & -19.01 \\
6NWV070 & -115.5972 & 39.9057 & 2056.2 & 979545.11 & 18.76 & 2.07 & -210.76 & -6.96 \\
\hline & & & & & & & &
\end{tabular}


Table 2. Cenozoic density-depth function for the Newark Valley study area.

\begin{tabular}{|c|c|c|}
\hline $\begin{array}{c}\text { Depth Range } \\
\text { (km) }\end{array}$ & $\begin{array}{c}\text { Sedimentary rocks } \\
\qquad\left(\mathrm{kg} / \mathrm{m}^{3}\right)\end{array}$ & $\begin{array}{c}\text { Volcanic rocks } \\
\qquad\left(\mathrm{kg} / \mathrm{m}^{3}\right)\end{array}$ \\
\hline 0 to 0.2 & 2020 & 2220 \\
\hline 0.2 to 0.6 & 2120 & 2270 \\
\hline 0.6 to 1.2 & 2320 & 2320 \\
\hline$>1.2$ & 2420 & 2420 \\
\hline
\end{tabular}

